\title{
MANAGEMENT OF IMPORT ADMINISTRATION DOCUMENTS OF TOBACCO THROUGH FREIGHT FORWARDER USING FAULT TREE ANALYSIS (FTA) ON SHIPMENT STRENGTHS IN PT ALCOTRAINDO BATAM
}

\author{
$1^{\text {st }}$ Kusmiyati \\ Department Business Management \\ Politeknik Negeri Batam \\ Batam, Kepulauan Riau Indonesia \\ kusmiyati1306@gmail.com
}

Abstract-Import administration is a series of routine activities in managing import documents when shipments arrive in Batam. The benefits of the administration of tobacco imports at PT Alcotraindo Batam are very necessary to provide information in making decisions and facilitate the delivery of key raw materials. In the administration of tobacco imports there are three document managements: management from management, quarantine management, and management of freight forwarders. The three problems to find out the root of the problem or the cause of the delay in the document are done by FTA (Fault Tree Analysis) method.

Keywords- Administration of Imports, Tobacco Document Management, FTA (Fault Tree Analysis).

\section{INTRODUCTION}

\section{A. Background}

A company conducts international trade because of the mutually needed economic conditions between the company and the international market, the existence of absolute and comparative advantages, and the development of technology in the field of communication and transportation ${ }^{[1]}$.

The import value of Riau Islands Province in September 2018 reached US \$ 979.03 million, down 3.25 percent compared to August 2018 imports. The largest supplier of imported goods in January-September 2018 was Singapore with a value of US $\$ 2,886.09$ million with contributions of 32, 43 percent. The biggest port for loading and unloading during January-September 2018 was Batu Ampar Port with import value of US \$ 4,337.74 million, Sekupang Port with an import value of US \$2,002.36 million, with both contributions accounted for 71.25 percent of total imports.

\author{
$2^{\text {nd }}$ Shinta Wahyu Hati \\ Department Business Management \\ Politeknik Negeri Batam \\ Batam, Kepulauan Riau Indonesia \\ Shinta@polibatam.ac.id
}

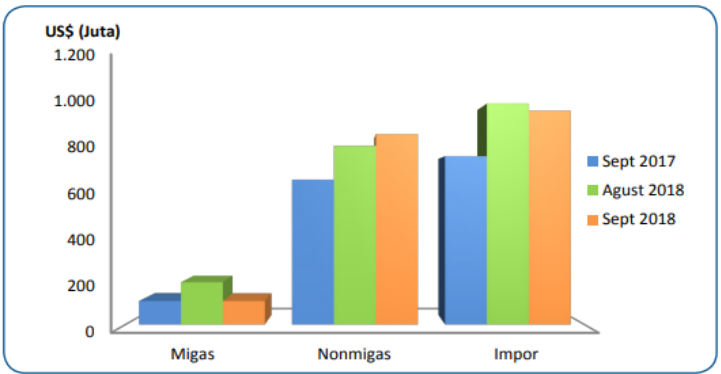

Fig. 1. Import Development of Riau Islands Province (Source: Central Bureau of Statistics, 2018)

B. Formulation of the problem

1. What is the administrative role in importing tobacco in PT Alcotraindo Batam?

2. How to identify administrative management of tobacco import documents at PT Alcotraindo Batam?

3. What is the management of tobacco import administration documents through freight forwarders on the smooth shipment at PT Alcotraindo Batam

\section{LITERATURE REVIEW}

Theoretical Framework

Administration

According to ${ }^{[2]}$, broad administration is a series of activities carried out by a group of people in an organization who work together to achieve certain goals.

\section{Document}

According to ${ }^{[3]}$, states that the document is a record of events that have passed. 


\section{Freight Forwarder}

According to ${ }^{[1]}$, he argued that Freight Forwarder is a document and transportation management service company on behalf of the shipper / consignee and carries out routine activities.

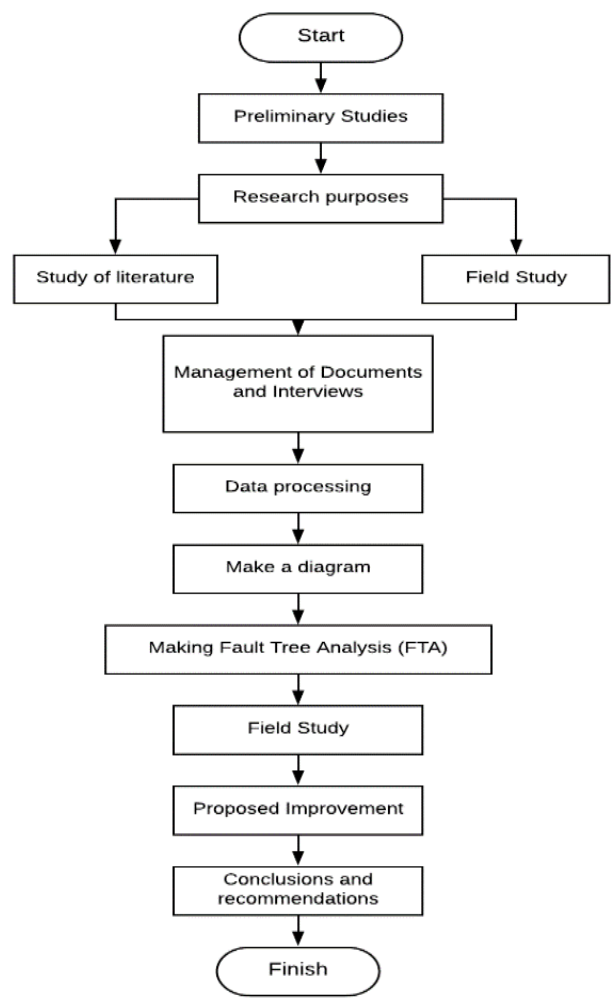

Fig. 2. Conceptual Framework

(Source: Research developed, 2019)

\section{METHODS OF RESEARCH}

\section{A. Method of Research of Research Design}

Research design is basically a procedural systematic plan that becomes a guide and prosecutor for researchers in answering research questions validly ${ }^{[3]}$. Data collection is needed to support the research process by document study, interview and observation. Then the data processing is carried out into the Fault Tree Analysis (FTA) method.

In this study the object under study is an administrative document on tobacco imports at PT Alcotraindo Batam. Meanwhile, the scope of the research includes all administrative documents on tobacco imports at PT Alcotraindo Batam. The variable operational according to ${ }^{[3]}$ is to define variables operationally based on observed characteristics and allow researchers to make observations or measurements carefully of an object or phenomenon.

\section{B. Operasional Variable}

TABLE I. OPERATIONAL DEFINITION OF THE RESEARCH VARIABLE

\begin{tabular}{|c|c|c|c|}
\hline $\begin{array}{l}\text { Concept of } \\
\text { Variables }\end{array}$ & Operational definition & Indicator & $\begin{array}{c}\text { Measurement } \\
\text { Scale }\end{array}$ \\
\hline $\begin{array}{l}\text { Management of } \\
\text { Import } \\
\text { Administrative } \\
\text { Documents }\end{array}$ & $\begin{array}{l}\text { The document is a record of events that } \\
\text { have passed. Documents can take the } \\
\text { form of writings, stories, biographies, } \\
\text { regulations, policies. [7] } \\
\text { - According to [4], Administration is } \\
\text { broadly a series of activities carried out } \\
\text { by a group of people in a collaboration to } \\
\text { achieve certain goals. }\end{array}$ & $\begin{array}{l}\text { 1. Knowing the procedures } \\
\text { for sorting import } \\
\text { documents needed } \\
\text { 2. Extensive knowledge } \\
\text { about imports } \\
\text { 3. Knowing submit data on } \\
\text { documents and inputting } \\
\text { into the quarantine iqfast } \\
\text { system }\end{array}$ & Nominal \\
\hline $\begin{array}{l}\text { Smoothness } \\
\text { Shipment }\end{array}$ & $\begin{array}{l}\text { According to [8], Freight Forwarder is a } 1 \\
\text { document handling and transportation } \\
\text { service company in the name of the shipper } \\
\text { consignee and carrying out routtine } \\
\text { activities such as stuffing / unstuffing } \\
\text { cargo, storage, warehousing, regulating } \\
\text { local transport, carrying out payments for } \\
\text { "ocean freight". The main role as a } \\
\text { shipping line. }\end{array}$ & 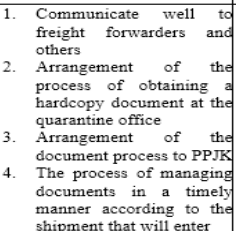 & Nominal \\
\hline
\end{tabular}

\section{Data Analysis Method}

According to ${ }^{[7]}$ the Fault Tree Analysis (FTA) method is a model diagram consisting of several sequentially which can cause the beginning of the failure event that has been set.

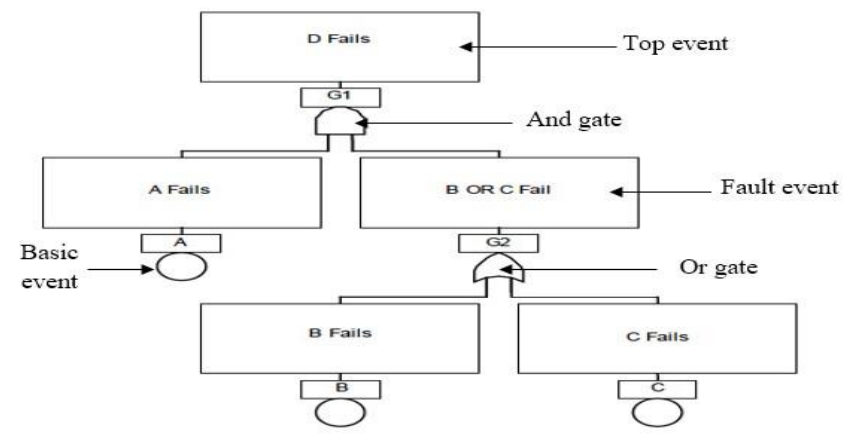

Fig. 3. Research Flow Chart

(Source : Fault tree handbook with aerospace applications, 2002)

\section{RESULTS AND DISCUSSION}

\section{Result}

The administrative role for PT Alcotraindo Batam is very important to help facilitate the implementation of key work tasks. Judging from the process, PT Alcotraindo Batam conducts the import administration process, mobilization, supervision until the goal achievement process. In terms of function, the overall activity of activities carried out by the logistics department and director of PT Alcotraindo Batam occupied top management. In terms of security, the administration carried out by PT Alcotraindo Batam is defined as an institution that is in line with ${ }^{[6]}$. 


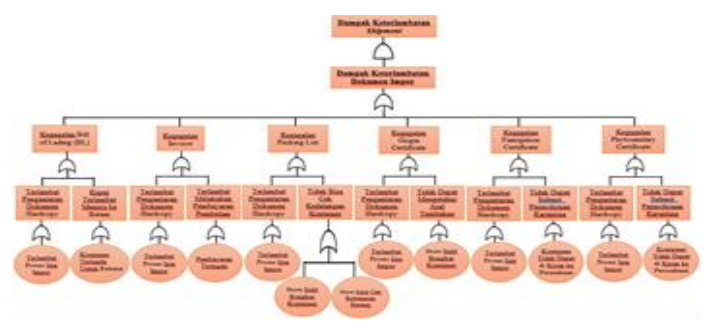

Fig. 4. Diagram of FTA Management Document

TABLE II. POTENTIAL ERRORS THAT OCCUR IN THE MANAGEMENT

\begin{tabular}{|c|c|c|c|}
\hline No & $\begin{array}{c}\text { Document } \\
\text { Management } \\
\text { Process }\end{array}$ & $\begin{array}{l}\text { Description of Findings in the } \\
\text { Process of Using Document } \\
\text { Management } \\
\text { Fault Tree Analysis }\end{array}$ & Risk \\
\hline 1. & $\begin{array}{l}\text { Management } \\
\text { (Logistics and Store) }\end{array}$ & $\begin{array}{l}\text { a. Delay documents from } \\
\text { shipper } \\
\text { b. Delay delivery container } \\
\text { c. warehouse capacity } \\
\text { d. Delay unloading container }\end{array}$ & $\begin{array}{l}\text { 1. Barang tidak } \\
\text { dapat diterima } \\
\text { 2. Production is } \\
\text { stopped } \\
\text { 3. Items cannot be } \\
\text { entered } \\
\text { 4. Make payment of } \\
\text { fines }\end{array}$ \\
\hline
\end{tabular}

TABLE III. POTENTIAL MISTAKES THAT OCCUR IN THE QUARANTINE

\begin{tabular}{|c|c|c|c|}
\hline No & $\begin{array}{c}\text { Document } \\
\text { Management } \\
\text { Process }\end{array}$ & $\begin{array}{c}\text { Description of Findings in the } \\
\text { Process of Using Document } \\
\text { Management } \\
\text { Fault Tree Analvsis }\end{array}$ & Risk \\
\hline 1. & $\begin{array}{l}\text { Quarantine } \\
\text { (Implementing and } \\
\text { Responsible) }\end{array}$ & $\begin{array}{l}\text { a. Manual Application } \\
\text { b. Incomplete document } \\
\text { c. Requirements to fulfill } \\
\text { documents }\end{array}$ & $\begin{array}{l}\text { 1. Longer time needed } \\
\text { 2. Application rejected } \\
\text { 3. KT-2 document is } \\
\text { signed }\end{array}$ \\
\hline
\end{tabular}

TABLE IV. POTENTIAL ERRORS THAT OCCUR IN THE FREIGHT FORWARDER

\begin{tabular}{|c|l|c|l|}
\hline No & $\begin{array}{c}\text { Document } \\
\text { Management } \\
\text { Process }\end{array}$ & $\begin{array}{c}\text { Description of Findings in the } \\
\text { Process of Using Document } \\
\text { Management } \\
\text { Fault Tree Analysis }\end{array}$ & \multicolumn{1}{c|}{ Risk } \\
\hline 1. & $\begin{array}{l}\text { Freight Forwarder } \\
\text { (Customs Control } \\
\text { Document) }\end{array}$ & $\begin{array}{l}\text { a. KT-2 does not accept } \\
\text { b. Many process steps are passed }\end{array}$ & $\begin{array}{l}\text { 1. SPPB is not processed } \\
\text { 2. Spend a lot of time } \\
\text { 3. There is pressure from } \\
\text { the Customer }\end{array}$ \\
\hline
\end{tabular}

At the root of the tree in the fault tree, the logistic and store area encounters a number of insignificant problems because of several errors and errors that result in unacceptable goods because the trigger is a delay in the shipper's sent documents, production cannot be stopped or stopped because the trigger is late delivery container to a designated warehouse, goods cannot be included because the trigger is inadequate warehouse capacity because it is full, and payment of fines occurs due to the trigger is the late process of unloading the container so that it exceeds the specified limit and gets a fine to be paid to trucking. In the root part of the tree in the fault tree, the Quarantine area, especially the Implementing and Responsible Section, encountered several insignificant problems because of several errors and errors resulting in longer time due to the trigger of manual requests made by service users, the application being rejected because the trigger was documents given or submitted to quarantine do not meet the prescribed requirements. In the root part of the tree in the fault tree, the Quarantine area, especially the Implementing and Responsible Section, encountered several insignificant problems because of several errors and errors resulting in the SPPB not being processed by KT-2 not or slowly being received by freight forwarders.

\section{Discussion}

\section{1) The role of administration in tobacco imports at PT Alcotraindo Batam}

Basically the administration system has a very important role for PT Alcotraindo Batam, because it can help companies in providing information or data needed to make decisions in the implementation of work task. The administration of administrative documents for the import of tobacco is processed through the Batam Class I Quarantine Center which is carried out regularly by PT Alcotraindo Batam. The process carried out is to submit IQFAST System facilitated by Quarantine in order to facilitate PT Alcotraindo Batam or other importers to input the data needed to obtain the KT-2 Letter in importing goods.

\section{2) Identification of Administration Management of Tobacco Import Documents at PT Alcotraindo Batam}

The consignee or PT Alcotraindo will receive the KT-2 Letter because it has been declared to meet the requirements of the quarantine standard. The KT-2 letter is submitted to the freight forwarders along with supporting documents such as Bill of Lading, Invoice, Packing List as a requirement for imported shipments which documents will be processed to the Batam Customs and Excise office.

PT Permindo Ekspress Batam or as a freight forwarder informs the recipients or goods owners of PT Alcotraindo Batam that the goods will be released immediately and trucking or container carriers immediately deliver goods to the warehouse location of PT Alcotraindo Batam. The container will be received by the store department.

3) Management of tobacco import administrative documents through freight forwarders on smooth shipment PT Alcotraindo Batam

In line with ${ }^{[8]}$ states that Freight Forwarders are not responsible for improper injury of goods. The tasks carried out by PT Permindo Ekspress Batam as a Freight Forwarder agent are: processing licensing documents until obtaining SPPB and goods belonging to PT Alcotraindo can be issued from Batu Ampar Port Batam.

Sellers, importers, freight forwarders, company transportation officers and customs are identified as executors and main participants. Plans for repairs that must be carried 
out by PT Permindo Ekspress Batam as Freight Forwarders are:

a. Customs and Excise must upgrade to prevent human error from processing smoothly

b. Between related agencies should have been connected to each other so that there is no delay in shipments entering Batam

\section{CONCLUSIONS \& RECOMMENDATIONS}

\section{Conclusions}

1. In the process of administration of tobacco imports it is processed through Quarantine carried out by PT Alcotraindo Batam regularly every time to process import documents on Iqfast (online service system) created by the Quarantine Agency specifically for importing companies.

2. PT Alcotraindo Batam are the management of imported documents processed by three parties from management, Quarantine and Freight Forwarders. The initial phase of the logistics department must obtain import documents from Shipper to be processed into Quarantine and will be given to PT Permindo Ekspress Batam as a Freight Forwarder agent. Furthermore, the Freight Forwarder will process the documents from PT Alcotraindo Batam to the Customs Office of Batam to obtain a Declaration of Goods Release.

3. PT Permindo Ekspress Batam Freight Forwarder as an intermediary in processing import documents to the Batam Customs and Excise Office until they are released from Batu Ampar Port Batam. Document management using the FAULT TREE ANALYSIS method is a number of potential errors that can occur during the work process that do not take place well from PT Alcotraindo Batam, Quarantine and Freight Forwarders

\section{Recommendations}

1. Expected to prioritize the speed of documents sent by the shipper before the container arrives dibatam.

2. Expected that the process of managing the administration of tobacco imports carried out is truly carried out by a competent person in the field, so that there will be no errors or inaccuracies in the process of managing import documents.

3. PT. Permindo Ekspress Batam as an agent of a Freight Forwarder company, is also expected to be carried out by a competent person to conduct freight forwarder management and also someone who is already experienced in doing the work, in order to really take into account the factors causing errors or delays in document.

\section{REFERENCES}

[1] Susilo, A. (2008). Smart Export-Import Book. Jakarta: Transmedia

[2] Gie, L. (2009). Modern Office Administration. Yogyakarta: Liberty

[3] Sugiyono (2013). Metode Penelitian Pendidikan Pendekatan Kuantitatif, Kualitatif, dan R\&D. Bandung: Alfabeta.

[4] Gie, L. (2009). Modern Office Administration. Yogyakarta: Liberty

[5] Echdar, S. (2017). Management and Business Research Methods. Bogor: Ghalia Indonesia. (references)

[6] Silalahi, U. (2003). Study of Administrative Sciences. Bandung: Sinar Baru Aglesindo

[7] Setyadi, I. (2013). Analysis of the Causes of Disability of Jeans Pants Products Using the Fault Tree Analysis (Fta) and Failure Mode And Effect Analysis (Fmea) Methods on CV. Fragile Din Co. University Widyatama.

[8] Tushevska, B. (2015). Liability of the Freight Forwarders According to National and International Law. (accessed on Agustus 12, 2015). (references) 